\title{
Skrining Aktivitas Antibakteri Dan Identifikasi Sponge Dari Teluk Kupang
}

\section{Agus Trianto 1,2*, Ni Komang Tri Utami', Ocky Karna Radjasa ${ }^{1,2}$ Isai Yusidharta ${ }^{3}$, Wiratno ${ }^{3}$}

\author{
'Departemen IImu Kelautan, Fakultas Perikanan dan IImu kelautan, Universitas Diponegoro \\ JI. Prof. Soedarto, SH. Kampus UNDIP Tembalang, Semarang 50275 \\ 2Laboratorium Marine Natural Product, UPT Lab terpadu, Universitas Diponegoro \\ JI. Prof. Soedarto, SH. Kampus UNDIP Tembalang, Semarang 50275 \\ 3BALAI BESAR KSDA Nusa Tenggara Timur \\ J. Perintis Kemerdekaan, Kelapa Lima, Kota Kupang, Nusa Tenggara Timur \\ Email:agustrianto.undip@gmail.com
}

\begin{abstract}
Recently, many research proved that bacteria Escherichia coli and Staphylococus aureus have resistant to antibiotics, called Multi Drug Resistance (MDR). The bacteria cause various diseases both in humans and animals. Exploration and development of new antibiotics is needed, one which is derived from a sea sponge. This research aims to determine the potential of antibacterial sponge extracts from the waters of Kupang, East Nusa Tenggara against E. coli and S. aureus MDR, as well as being able to identify the sponge. Maceration method was employed on extraction of the sponges, then the extract were tested against $E$. coli and S. aureus. The extracts content of sponge varied from $0.4 \%$ to 5,19\%. Anti bacterial test showed that the sponge K14-52 has the highest inhibition zone of 10,43 $\pm 0,26 \mathrm{~mm}$ and 9,38 $\pm 0,57 \mathrm{~mm}$ and against the E. coli and S. Aureus, respectively, at a concentration of $500 \mathrm{ug} / \mathrm{disk}$. Based on macroscopic and microscopic anayses, the K14-52 sponge is identified as Rhabdastrella globostellata. a Demospongia sponge. The sponge has special characteristic i.e. globular shape with large oscula on the top of the sponge and ostia along the surface. The sponge also characterized with makrosclera monoaxon spikule (hastate oxea, centrotylote oxea, oxea fusiform gyrus) and mikrosclera tertaxon oxyaster spikule.
\end{abstract}

Keywords: Antibacterial, Sponges, Staphylococcus aureus, Escherichia coli

\begin{abstract}
Abstrak
Saat ini banyak ditemukan bakteri Escherichia coli dan Staphylococus aureus yang resisten terhadap antibiotik atau disebut Multi Drugs Resistance (MDR). Bakteri tersebut dapat menimbulkan berbagai penyakit baik pada manusia maupun hewan. Eksplorasi dan pengembangan sumber antibiotik baru sangat diperlukan, salah satunya yang berasal dari sponge laut. Penelitian ini bertujuan untuk mengetahui potensi antibakteri ekstrak sponge dari Perairan Kupang, Nusa Tenggara Timur terhadap bakteri E. coli dan S. aureus MDR, serta mampu mengetahui jenis sponge. Ekstraksi dilakukan dengan metoda maserasi kemudian ekstrak diuji terhadap bakteri patogen. Uji antibakteri menunjukkan bahwa sponge K14-52 memiliki potensi antibakteri paling tinggi dengan zona hambat sebesar 10,43 $\pm 0,26 \mathrm{~mm}$

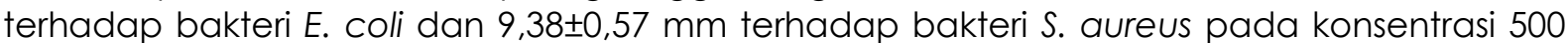
$\mu \mathrm{g} /$ disk. Sponge K14-52 diidentifikasi sebagai Rhabdastrella globostellata berdasarkan analisis secara makroskopis dan mikroskopis. Ciri khas sponge tersebut adalah mempunyai bentuk bulat dengan ostia yang tersebar pada permukaan dan satu Oskula besar pada bagian atas sponge. Secara mikroskopis sponge tersebut memiliki makrosklera monoaxon spikula (hastate oxea, centrotylote oxea, fusiform oxea) dan mikrosklera tertaxon spikula Oxyaster.
\end{abstract}

Kata kunci: Antibakteri, Sponge, Identifikasi Sponge 



\section{PENDAHULUAN}

Saat ini banyak ditemukan bakteri Stapylococcus aureus dan Escherichia coli yang resisten terhadap antibiotik atau biasa disebut Multi Drugs Resistance (MDR) (Satari, 2012). Bakteri S. aureus dan E.coli menyebabkan berbagai penyakit pada manusia dan hewan ternak. Berubahnya sifat pathogen menjadi MDR menyebabkan obat yang biasa digunakan menjadi tidak efektif, sehingga tidak dapat menanggulangi penyakit tersebut (Widagdo et al., 2002). Resistensi pathogen timbl akibat penggunaan obat yang tidak tepat, naik dosis maupun jenisnya (Pastra et al., 2012). Pencarian obat baru dengan mode of action yang baru adalah salah satu solusi untuk mengatasi permasalahan pathogen MDR. Banyak sumber daya laut dikembangkan untuk mencari antibakteri alami dari sponge (Mehbub et al., 2016)

Sponge adalah salah satu biota laut yang paling potensial sebagai sumber senyawa antibakteri. Senyawa bioaktif sponge dihasilkan oleh metabolit sekunder yang dimanfaatkan sebagai bahan obatobatan, misalnya antibakteri, antitumor, antikanker, antijamur, anti-inflamantori, sitotoksik, antimikroba, antivirus, antimalaria, antifauling, dan immunosupresif (Mayer et al., 2009). Tulisan ini akan membahas eksplorasi sponge sebagai sumber bahan antibakteri.

\section{MATERI DAN METODE}

\section{Koleksi Spesimen Sponge}

Sponge yang dikoleksi dari perairan Kupang, Nusa Tenggara Timur dengan metoda SCUBA Diving. Sponge disimpan dalam coolbox yang diberi es hingga dibawa ke laboratorium untuk selanjutnya disimpan dalam freezer hingga proses ekstraksi (Trianto et al., 2011).

\section{Ekstraksi Sponge}

Sebelum melakukan ekstraksi, sampel dibersihkan dari kotoran yang menempel, kemudian dipotong kecil-kecil. Ekstraksi dilakukan dengan metode maserasi menggunakan methanol. Proses perendamanan dilakukan selama 24 jam dengan tiga kali ulangan pada suhu ruangan. Hasil ekstraksi disaring dan selanjutnya dipekatkan menggunakan Rotary Evaporator pada suhu $37{ }^{\circ} \mathrm{C}$. Ekstrak yang tertinggal dalam labu dipindahkan kedalam vial dan ditimbang (Trianto et al., 2014).

\section{Kultur Bakteri Uji}

Bakteri uji yaitu bakteri E. coli dan $S$. aureus dikultur dalam media Zobell $2216 \mathrm{E}$ dalam media miring. Bakteri uji dikultur kembali dalam media Zobell cair untuk uji antibakteri terhadap ekstrak (Radjasa et al., 2006).

\section{Uji Aktivitas Antibakteri}

Uji aktivitas antibakteri dilakukan dalam media Zobell padat selama $2 \times 24$ jam. Uji antibakteri pada 11 sampel ekstrak kasar sponge terhadap bakteri $E$. coli dan S. aureus pada konsentrasi 500 mg/disk, 250 $\mu \mathrm{g} / \mathrm{disk}, 100 \mu \mathrm{g} /$ disk, dan $50 \mu \mathrm{g} /$ disk. Ektsrak yang diaplikasikan sebanyak $10 \mu \mathrm{l} /$ disk. Pengukuran zona hambat pada jam ke 24 (Radjasa, 2006).

\section{Identifikasi Sponge}

Identifikasi sponge dilakukan pada sponge yang memiliki aktivitas antibakteri. Identifikasi makroskopis berdasarkan morfologi dan tekstur sponge yang meliputi ukuran, oskula, konsistensi, permukaan tubuh dan warna sponge. Sedangkan identifikasi mikroskopis meliputi bentuk dan jenis spikula sponge (Hooper, 2003). Preparat disiapkan dengan memotong sedikit sampel dan dilarutkan dengan sodium hypoklorit. Materi dibilas menggunakan aquades 2-3 kali untuk menghilangkan sisa kaporit, selanjutnya spikula diamati dengan mikroskop pada perbesaran $100 \times$ dan $400 \times$ (Khoshkhoo et al., 2012).

\section{HASIL DAN PEMBAHASAN}

\section{Ekstraksi}

Ekstraksi berbagai jenis sampel sponge menggunakan metode maserasi, yaitu melakukan perendaman sampel 
sponge dengan pelarut metanol selama 48 jam. Berat sampel dan ekstrak yang dihasilkan ditampilkan pada Tabel 1.

Berdasarkan data tersebut, diketahui bahwa sampel sponge K14-52 menghasilkan rendemen ekstrak tertinggi yaitu 5,19\% dari berat basah, sedangkan rendemen terkecil pada sampel sponge K14-35 yaitu hanya sebesar 0,48 \% dari berat basahnya.

\section{Uji Antibakteri Ekstrak Kasar}

Ekstrak kasar sponge kemudian diuji bioaktvitasnya terhadap bakteri E. coli dan S. aureus. Hasil uji antibakteri menunjukan ekstrak kasar semua jenis sponge tersebut mampu menghambat pertumbuhan koloni bakteri uji. Hasil pengukuran diameter zona hambat pada pengamatan ke-24 jam ditampilkan pada Ttabel 2 dan 3.

Hasil uji ekstrak kasar terhadap bakteri S. aureus menunjukkan bahwa sampel K14-52 menghasilkan zona hambat tertinggi sebesar 9,38 $\pm 0,12 \mathrm{~mm}$ pada konsentrasi $500 \mu \mathrm{g} /$ disk, sedangkan yang terendah dihasilkan oleh sponge K14-45 sebesar $0,72 \pm 1,01 \mathrm{~mm}$ pada konsentrasi yang sama. Hasil pengukuran diameter zona hambat ekstrak kasar berbagai sponge terhadap bakteri E. coli dan S. aureus.

Tabel 1. Berat Sampel dan Ektrak Kasar Sponge

\begin{tabular}{rcccc}
\hline No. & $\begin{array}{c}\text { Kode Sampel } \\
\text { Sponge }\end{array}$ & $\begin{array}{c}\text { Berat Basah } \\
\text { Sampel (gr) }\end{array}$ & $\begin{array}{c}\text { Berat Ekstrak } \\
\text { Kasar (gr) }\end{array}$ & $\begin{array}{c}\text { Rendemen Ekstrak } \\
(\%)\end{array}$ \\
\hline 1. & K-14-01 & 5.27 & 0.11 & 2.09 \\
2. & K-14-03 & 9.08 & 0.18 & 1.98 \\
3. & K-14-21 & 11.30 & 0.57 & 5.04 \\
4. & K-14-33 & 47.63 & 1.65 & 3.46 \\
5. & K-14-35 & 47.60 & 0.23 & 0.48 \\
6. & K-14-40 & 49.97 & 1.87 & 3.74 \\
7. & K-14-45 & 12.25 & 0.38 & 3.10 \\
8. & K-14-46 & 18.14 & 0.56 & 3.09 \\
9. & K-14-47 & 38.21 & 1.24 & 3.25 \\
10. & K-14-49 & 12.45 & 0.10 & 0.80 \\
11. & K-14-52 & 22.36 & 1.16 & 5.19 \\
\hline
\end{tabular}

Tabel 2. Diameter Zona Hambat Ekstrak Kasar Sponge terhadap Bakteri E. coli

\begin{tabular}{ccccc}
\hline \multirow{2}{*}{ Kode Sampel } & \multicolumn{4}{c}{ Diameter Zona Hambatan E. coli $(\mathrm{mm})$} \\
\cline { 2 - 5 } & $500 \mu \mathrm{g} /$ disk & $250 \mu \mathrm{g} /$ disk & $100 \mu \mathrm{g} /$ disk & $50 \mu \mathrm{g} /$ disk \\
\hline K-14-01 & $2,22 \pm 0,99$ & $2,92 \pm 0,07$ & $1,37 \pm 1,93$ & $2,23 \pm 0,38$ \\
K-14-03 & $2,73 \pm 0,61$ & $2,65 \pm 0,12$ & $2,67 \pm 0,90$ & $3,23 \pm 0,38$ \\
K-14-21 & $1,97 \pm 0,19$ & $1,22 \pm 1,72$ & $1,00 \pm 1,41$ & $3,03 \pm 0,05$ \\
K-14-33 & $2,70 \pm 0,28$ & $2,75 \pm 0,31$ & $2,27 \pm 0,09$ & $1,22 \pm 1,72$ \\
K-14-35 & $5,28 \pm 1,86$ & $4,10 \pm 0,05$ & $2,60 \pm 0,94$ & $2,52 \pm 0,97$ \\
K-14-40 & $2,83 \pm 0,85$ & $1,90 \pm 0,09$ & $0,68 \pm 0,97$ & $0,70 \pm 0,99$ \\
K-14-45 & $2,88 \pm 1,67$ & $3,40 \pm 0,94$ & $2,22 \pm 1,11$ & $3,02 \pm 0,87$ \\
K-14-46 & $2,68 \pm 0,78$ & $1,45 \pm 2,05$ & $1,30 \pm 1,84$ & $1,17 \pm 1,65$ \\
K-14-47 & $3,43 \pm 1,98$ & $2,43 \pm 0,42$ & $2,83 \pm 1,60$ & $1,83 \pm 0,24$ \\
K-14-49 & $1,37 \pm 1,93$ & $1,45 \pm 2,05$ & $2,38 \pm 0,26$ & $3,68 \pm 1,11$ \\
K-14-52 & $10,43 \pm 0,24$ & $8,57 \pm 0,19$ & $6,32 \pm 0,26$ & $4,82 \pm 0,07$ \\
\hline
\end{tabular}

Keterangan : - Rata-rata \pm Standar Deviasi

- Data tersebut telah dikurangi diameter paper disk sebesar $5 \mathrm{~mm}$ 


\section{Identifikasi Sponge}

Sponge K14-52 berwarna kuningoranye, bentuk tubuh globular dengan permukaan sponge yang kasar. Ostia tampak jelas tersebur tidak beraturan pada permukaan. Sponge untuk mempunyai konsistensi yang keras (incompressible).
Berdasarkan

pengamatan preparat spikula, ditemukan dua jenis spikula yaitu makroskelra dan mikroskelra. Jenis makrosklera yang ditemukan yaitu hastate oxea, centrotylote oxea, dan fusiform oxea, merupakan monoaxon spikula berbentuk spikula memanjang dan ada yang agak melengkung dengan ujung runcing di kedua ujungnya. Sedangkan

Tabel 3. Diameter Zona Hambat Ekstrak Kasar Sponge terhadap Bakteri S. aureus.

\begin{tabular}{ccccc}
\hline \multirow{2}{*}{ Kode Sampel } & \multicolumn{4}{c}{ Diameter Zona Hambatan S. aureus (mm) } \\
\cline { 2 - 5 } & $500 \mu \mathrm{m} /$ disk & $250 \mu \mathrm{g} /$ disk & $100 \mu \mathrm{g} /$ disk & $50 \mu \mathrm{g} / \mathrm{disk}$ \\
\hline K-14-01 & $2,22 \pm 0,92$ & $2,92 \pm 0,07$ & $1,37 \pm 2,23$ & $2,23 \pm 0,38$ \\
K-14-03 & $2,73 \pm 0,61$ & $2,65 \pm 0,12$ & $2,67 \pm 0,90$ & $3,23 \pm 0,38$ \\
K-14-21 & $1,97 \pm 0,19$ & $1,22 \pm 1,72$ & $1,00 \pm 1,41$ & $3,03 \pm 0,05$ \\
K-14-33 & $2,70 \pm 0,28$ & $2,75 \pm 0,31$ & $2,27 \pm 0,09$ & $1,22 \pm 1,72$ \\
K-14-35 & $3,52 \pm 0,08$ & $4,75 \pm 4,45$ & $2,77 \pm 1,41$ & $1,68 \pm 0,35$ \\
K-14-40 & $1,02 \pm 1,44$ & $2,47 \pm 0,05$ & $0,00 \pm 0,00$ & $0,00 \pm 0,00$ \\
K-14-45 & $0,72 \pm 1,01$ & $0,98 \pm 1,39$ & $1,83 \pm 0,01$ & $3,00 \pm 0,05$ \\
K-14-46 & $2,30 \pm 0,71$ & $2,70 \pm 0,05$ & $1,85 \pm 2,62$ & $2,57 \pm 0,47$ \\
K-14-47 & $3,38 \pm 0,73$ & $2,57 \pm 0,94$ & $1,88 \pm 0,16$ & $2,07 \pm 0,14$ \\
K-14-49 & $2,45 \pm 0,12$ & $2,53 \pm 0,05$ & $3,45 \pm 0,78$ & $4,78 \pm 1,11$ \\
K-14-52 & $9,38 \pm 0,12$ & $7,73 \pm 0,57$ & $6,45 \pm 0,07$ & $4,57 \pm 0,14$ \\
\hline
\end{tabular}

Keterangan: - Rata-rata \pm Standar Deviasi

- Data tersebut telah dikurangi diameter paper disk sebesar $5 \mathrm{~mm}$

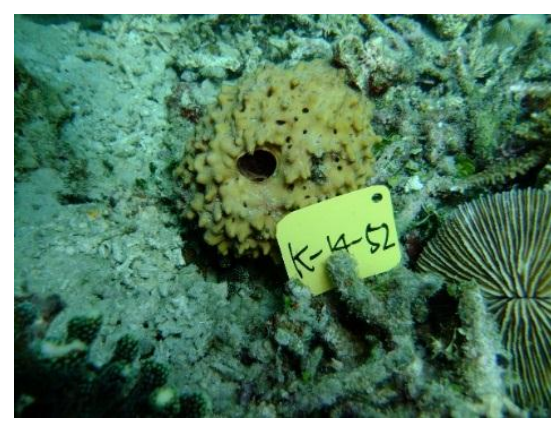

(a)

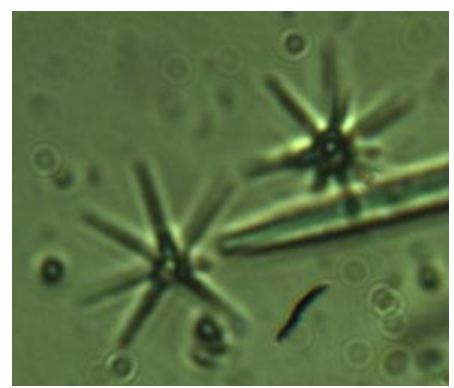

(b)

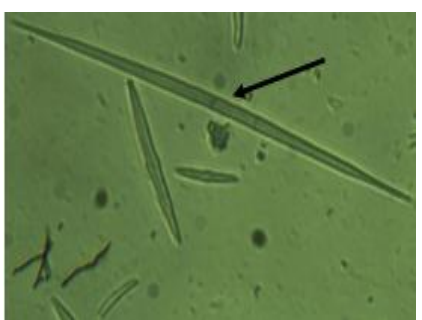

(e)

(c)

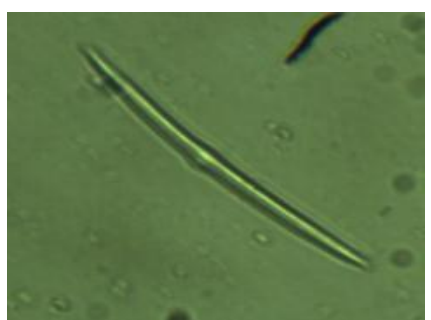

(d)

Gambar 1. Foto sponge K14-52 (a), mikrosklerit (b) dan makroskerit (c-e). makrosklerit (c-e). b. Tetraxon (Oxyasters) c. Monoaxon spikula Hastate oxea, d. Centrotylote oxea, e. Fusiform oxea. Foto mikroskelarit diambil pada perbesaran 100x dan makrosklerit dengan perbesaran 40x. 
yang mikroskela yang ditemukan yaitu oxyaster, masuk ke dalam jenis tetraxon spikula berbentuk bulat dengan beberapa ujung runcing yang mengelilingi sisi-sisinya. Hasil pengamatan makrosklera, dapat dilihat pada Gambar 10 dan mikrosklera pada Gambar 11.

Spikula penyusun sponge K14-52 mengandung silikat atau seperti kaca bukan kapur sehingga tidak mudah hancur pada saat dilarutkan pada larutan pemutih.

Ekstraksi menggunakan metanol menghasilkan prosentase rendemen ekstrak yang berbeda pada tiap sampel. Rendemen ekstrak tertinggi dihasilkan oleh sampel sponge K14-52 yaitu sebesar 5,19\% dari berat basah sampel sebesar 22,36 gram. Sedangkan yang rendemen ekstrak terendah dihasilkan oleh sponge K14-35 yaitu sebesar $0,48 \%$ dari berat basah sampel sebesar 47,60 gram.

Hasil pengamatan zona hambat setelah 24 jam inkubasi menunjukkan bahwa seluruh ekstrak kasar yaitu 11 sampel ekstrak kasar yang diuji mempunyai kemampuan menghambat pertumbuhan koloni bakteri dengan besar zona hambat yang berbeda-beda. Ekstrak kasar sampel sponge K14-52 memiliki zona hambat yang paling besar dengan diameter zona hambat mencapai $10,43 \pm 0,26 \mathrm{~mm}$ pada konsentrasi $500 \mu \mathrm{g} /$ disk terhadap bakteri E.coli, dan semakin mengecil pada konsentrasi yang lebih rendah. Sedangkan uji terhadap bakteri S. aureus menghasilkan zona hambat dengan diameter 9,38 $\pm 0,57$ $\mathrm{mm}$. Berdasarkan hasil tersebut dapat diketahui bahwa sampel sponge K14-52 mempunyai zona hambat yang masuk ke dalam kategori kuat dengan membentuk daerah hambatan 10-20 mm. Menurut Tinambunan et al. (2012), antibakteri dikatakan mempunyai aktivitas yang tinggi terhadap mikroba apabila konsentrasi hambat minimumnya rendah tetapi mempunyai daya hambat yang besar.

Fraksinasi dengan etil asetat dan air menghasilkan pemisahan senyawa nonpolar dan senyawa polar yang terkandung dalam ekstrak tersebut. Air merupakan pelarut polar sehingga akan menarik senyawa yang bersifat polar, sedangkan etil asetat merupakan pelarut semi-polar sehingga akan mengikat senyawa yang tingkat polaritasnya rendah. Pemisahan tersebut juga dapat dikatakan sempurna apabila kedua lapisan memiliki perbedaan warna yang jelas dan larutan tidak keruh. Pada ekstrak sampel K14-52, fraksi air berwarna kuning pekat sedangkan fraksi etil asetat berwarna kuning bening. Berat ekstrak fraksi etil asetat yaitu $330,6 \mathrm{mg}$ sedangkan berat ekstrak fraksi air adalah $732,6 \mathrm{mg}$. Berat ekstrak fraksi etil asetat lebih kecil dibandingkan dengan fraksi air menunjukkan bahwa ekstrak sponge K1452 lebih banyak larut pada pelarut polar dibandingkan dengan pelarut semi-polar.

Berdasarkan hasil identifikasi morfologi sponge, yaitu sponge K14-52 berwarna kuning-oranye, bentuk tubuh agak membulat dengan permukaan sponge yang kasar. Saluran masuk air ke dalam tubuh sponge melalui pori-pori kecil (ostia) terletak tidak beraturan tampak lebih jelas karena memiliki ukuran yang lebih besar dan berada pada bagian atas tubuh sponge. Saluran air keluar melalui oskula yang terdapat pada ujung atas sponge. Konsistensi sponge keras dan agak padat (non-kompressible). Menurut Hooper (2003) family Ancorinidae (SCHMIDT, 1870.) dicirikan dengan bentuk pertumbuhan encrusting hingga masif atau lebih spesifik berbentuk bulat atau pipa dengan saluran air memanjang dimana saluran masuk dan keluar pada sisi yang berlawanan. Lebih spesifik genus Rhabdastrella dalam family Ancorinidae yang dicirikan tidak adanya oskula yang memanjang pada koloni yang berbentuk pipa panjang.

Makroskela yang ditemukan yaitu monoaxon spikula (hastate oxea, centrotylote oxea, dan fusiform oxea). Hastate oxea merupakan spikula dengan bentuk panjang dan ujung tidak terlalu runcing di kedua bagian ujungnya, centrotylote oxea merupakan spikula dengan bentuk memanjang dan runcing di kedua bagaian ujungnya dan memiliki bentuk bulatan pada bagian sentral atau tengah spikula, sedangkan fusiform oxea 
merupakan spikula memanjang dan memiliki ujung runcing di kedua ujungnya. Pada pengamatan yang dilakukan pada sponge K14-52 ditemukan sedikit mikrosklera tetraxon yaitu spikula berbentuk bulat dengan beberapa ujung runcing di bagian sisinya yang berjumlah enam buah, disebut dengan oxyasters. Lebih lanjut hooper menjelaskan bahwa family Ancorinidae dicirikan dengan megascleres long-shafted triaenes dan oxea megascleres; microscleres evasters and microrhabds, tetapi tidak memiliki sterrasters atau amphiasters. Pada genus Rhabdastrella tidak ditemui spikula triene. Berdasarkan hasil identifikasi tersebut, diduga sponge K14-52 termasuk kelas Demospongia dan genus Rhabdastrella.

Beberapa penelitian membuktikan bahwa sponge R. globostelata adalah pengahasil bahan bioaktif antikanker. Sponge $R$. globostelata dilaporkan mengandung senyawa globostellatic acid $X$ methyl esters yang bersifat sebagai antiangiogenic dengan menghambat pertumbuhan vascular endothelial growth factor (VEGF) dan basic fibroblast growth factor (bFGF). Selain itu senyawa tersebut juga bersifat selective anti-proliferative agents terhadap human umbilical vein endothelial cells (HUVECs). Dengan demikian globostellatic acid X methyl esters berpotensi sebagai senyawa antikanker padat, karena pertumbuhan kanker padat berkorelasi dengan pertumbuhan/proses vaskularisasi (Aoki et al., 2007). Namun, sepanjang pengetahuan penulis, sejauh ini belum ada laporan tentang kandungan senyawa antibakteri pada sponge $R$. globostellata.

\section{Kesimpulan}

Ekstrak sponge yang dikoleksi dari Perairan Kupang, Nusa Tenggara Timur memiliki potensi antibakteri terhadap bakteri Escherichia coli dan Staphyloccocus aureus. Berdasarkan hasil identifikasi makroskopis dan mikroskopis sampel sponge diketahui bahwa sponge K14-52 masuk ke dalam kelas Demospongia dengan spesies Rhabdastrella globostellata, dikarenakan memiliki makroskela monoaxon spikula (Hastate oxea, Centrotylote oxea, dan Fusiform oxea) dan mikrosklera jenis tetraxon spikula (oxyastes).

\section{Daftar Pustaka}

Aoki, S., Sanagawa, M., Watanabe, Y., Setiawan, A., Arai, M., \& Kobayashi, M. (2007). Novel isomarabarican triterpenes, exhibiting selective antiproliferative activity against vascular endothelial cells, from marine sponge Rhabdastrella globostellata. Bioorganic and Medicinal Chemistry, 15(14), 4818-4828. http://doi.org/10.10 16/j.bmc.2007.04.070

Hooper, J.N.A. 2003. Sponguide: Guide to Sponge Collection and Identification. Queensland Museum. South Brisbande, Australia

Indrayanti, E., Maskulah, M., dan Trianto, A.. 2003. Skrining pada Beberapa Jenis Sponge sebagai Upaya Pencarian Bahan Bioaktif Jamur. Fakultas Perikanan dan IImu Kelautan, Universitas Diponegoro, Semarang.

Khoshkhoo, Z., M. Nazemi, A. Motalebi, M. Mahdabi, A. Ashja Ardalan, and R. Hemati Matin. 2012. Fist Record of Siliceous and Calcareous Sponges from Larak Island, Persian Gulf-Iran. Middle-East J. Sci. Res. 11 (7) : 887-893.

Aoki, S., Sanagawa, M., Watanabe, Y., Setiawan, A., Arai, M., \& Kobayashi, M. (2007). Novel isomarabarican triterpenes, exhibiting selective antiproliferative activity against vascular endothelial cells, from marine sponge Rhabdastrella globostellata. Bioorganic and Medicinal Chemistry, 15(14), 4818-4828. http://doi.org/10.10 16/j.bmc.2007.04.070

Mayer, A. M. S., Rodríguez, A. D., Berlinck, R. G. S., \& Hamann, M. T. (2009). Marine pharmacology in 2005-6: Marine compounds with anthelmintic, antibacterial, anticoagulant, antifungal, anti-inflammatory, antimalarial, antiprotozoal, antituberculosis, and antiviral activities; affecting the cardiovascular, immune and nervous syste. Biochimica et Biophysica Acta General Subjects, 1790(5), 283-308. 
http://doi.org/10.1016/j.bbagen.2009. 03.011

Mehbub, M. F., Perkins, M. V., Zhang, W., \& Franco, C. M. M. (2016). New marine natural products from sponges (Porifera) of the order Dictyoceratida (2001 to 2012); a promising source for drug discovery, exploration and future prospects. Biotechnology Advances. http://doi.org/10.1016/j.biotechadv.20 15.12.008

Pastra, D.A., Melki, dan Heron S. 2012. Penapisan bakteri yang Bersimbiosis dengan Sponge Jenis Aplysina sp sebagai Penghasil Antibakteri dari Perairan Pulau Tegal Lampung. Maspari Journal, 4 (1): 77 - 82

Radjasa, O.K., Sabdono A., Duhita S.K., Rory A.H., dan.Lestari E.S. 2007. Antibacterial Activity of Marine Bacteria Associated with Sponge Aoptos sp. Against Multi Drugs Resistant (MDR) Strains. Jurnal Matematika dan Sains, 12 (4).

Satari, M. H. 2012. Multidrugs Resistance (MDR) Bakteri Terhadap Antibiotik. Prosiding Temu llmiah Bandung. Bagian Oral Biologi/Mikrobiologi FKG Universitas Padjadjaran.

Suriani, Hanapi U., dan Alyar A. 2012. Isolasi, Karakterisasi, dan Uji Bioaktifitas Metabolit Sekunder dari Sponge
Callyspongia sp. Marina Cimica Arta, 12

Tinambuan, H., Melki dan Isnaini. 2012. Efektifitas Ekstrak Bakteri yang Berasosiasi dengan Sponge dan Karang Lunak sebagai Antibakteri dari Perairan Pulau Tegal Lampung. Maspari Journal, 4 (2) : $225-230$

Trianto, A., Hermawan I., De Voogd N.J., and Tanaka J., 2011, Halioxepine, A New Meroditerpene From An Indonesian Spons Haliclona sp. Chem. Pharm. Bull. . 59(10):1311-3.

Trianto, A., De Voodg N.J., and Tanaka J.. 2014. Two new compound from an Indonesian Sponge Dysea sp. J. Asian Natural Product Research. J. Asian Nat. Prod. Res., 16(2):163-168. DOI: $10.1080 / 10286020.2013 .844128$.

Uriz, M. J., Turon X., Mikel A.B, and Agell G. 2003. Siliceous Spicules and Skeleton Frameworks in Sponges : Origin, Diversity, Ultrastructural Patterns, and Biological Functions. Microscopy Research and Technique. $62: 279-299$

Widagdo, S.N., Haryadi M., dan Widya A. 2002. Patogenesis Isolat Escherichia coli Positif Congo Red pada Telur Ayam Berembrio Umur 12 Hari. Jurnal Sain Veteriner, XX (1):25-28 